\title{
How to Prevent School Shootings and Other Mass Homicides
}

\section{Keith Burgess-Jackson}

The University of Texas at Arlington, Arlington, TX, USA

Email:kbj@uta.edu

How to cite this paper: Burgess-Jackson, K. (2019). How to Prevent School Shootings and Other Mass Homicides. Beijing Law Review, 10, 1409-1430. https://doi.org/10.4236/blr.2019.105076

Received: November 26, 2019 Accepted: December 28, 2019

Published: December 31, 2019

Copyright $\odot 2019$ by author(s) and Scientific Research Publishing Inc. This work is licensed under the Creative Commons Attribution International License (CC BY 4.0).

http://creativecommons.org/licenses/by/4.0/

\section{Open Access}

\begin{abstract}
Mass homicides, of which school shootings are a species, are all too common. What makes them philosophically interesting is that the usual punishments for such crimes are ineffective. How does one deter a person who is intent on killing himself or herself upon completion of the massacre? After clarifying the concepts of prevention, deterrence, and punishment, I describe various modes of punishment. If we are serious about preventing mass homicides, we must not rule out any mode of punishment a priori. I suggest several punishments, such as torture and imprisonment with hard labor, that may deter prospective mass murderers. The aim is to find a punishment that the prospective mass murderer fears more than death. I also recommend the inculcation of theism (understood as belief in a retributive god) as a means of deterring mass homicides.
\end{abstract}

\section{Keywords}

School Shootings, Mass Homicides, Massacres, Jeremy Bentham (1748-1832), Crime, Punishment, Crime Prevention, Rehabilitation, Incapacitation,

Deterrence, Torture, Imprisonment, Hard Labor, Theism

\section{Introduction}

The principal end of punishments is to prevent like offences. The past offence is only as one point; the future is infinite. The past offence concerns only one individual; similar offences may affect every one. In many cases, the evil committed is irreparable; but the will to do evil may always be taken away, because, how great soever the advantage of the offence may be, the evil of the punishment may be made to surpass it (Bentham, 1843: p. 367). ${ }^{1}$

${ }^{1}$ Bentham later adds (1843: p. 400): "That it may prove effectual, the punishment must be more dreaded than the profit of the crime desired." Bentham is still worth reading on the subject of crime and punishment. He thought longer and harder than anyone else, before or since, about punishment, and he thought longer and harder about punishment than about any other topic. For an overview of Bentham's contributions to criminology, see Geis, 1955. 
To me it seems obvious that if by torturing one child you could prevent a vast number of children (and adults) suffering as much [as] or more than the child you have to torture, it would be wrong not to torture that child (Singer, 2016: p. 70; italics in original).

As I write these words, in May 2018, there has been another in a seemingly endless succession of school shootings. The latest incident, in Santa Fe, Texas, resulted in 10 deaths and at least as many injuries. The culprit, a student at the local high school, was taken into custody by authorities before he could do further damage to his classmates and teachers. His weapons included a sawed-off shotgun and a .38-caliber handgun, both of which were owned by his father. $\mathrm{He}$ had also prepared several explosive devices, though none of them, mercifully, was detonated. ${ }^{2}$

It is beyond frustrating that these incidents continue to occur. It is infuriating. Innocent lives, many of them just beginning, are snuffed out. Those who are killed lose all opportunity for experiences, enjoyments, activities, and projects-everything that gives life meaning and makes it worthwhile. Those who are maimed and wounded must live not just with physical disabilities of various sorts, each of which adversely affects the quality of their lives, but with the awful memory of what happened on that tragic day. Families are torn apart; friendships are destroyed; communities are traumatized. The effect of a mass homicide is not unlike that of a natural disaster.

Much of the frustration and impotence felt by society following mass homicides stems from the fact that those who do the killings are indifferent to their own demise. Indeed, in some cases, as in the Santa Fe shootings, the perpetrator intends to kill himself or herself after killing others. How does society deter someone who is willing-perhaps even eager-to die? Although the Santa Fe shooter, who was 17 years of age at the time of his murders, is not eligible for the death penalty as a result of a 2005 Supreme Court ruling, ${ }^{3}$ others, who have reached the age of 18 and who happen to live in a state that has capital punishment, are. These individuals must know that they will, in all likelihood, be put to death eventually for their crimes. And yet they kill.

There are ways to prevent school shootings and other mass homicides. I do not claim that these methods will be successful in all cases, though I believe that they have a chance to be successful in some, nor do I claim that they should be implemented, all things considered. I am a philosopher, not a policymaker. My aim in this essay is to explore the logic of the situation, not its morality or its political feasibility. Whether society is prepared to bear the costs of prevention is for society to decide. My thesis must therefore be understood as a conditional: If society wishes to prevent school shootings and other mass homicides, then it

${ }^{2}$ The facts in this paragraph are taken from Fernandez, Fausset, \& Bidgood, 2018.

${ }^{3}$ Roper v. Simmons, 543 U.S. 551 (2005). He is also, by virtue of his status as a juvenile, ineligible for life imprisonment without the possibility of parole. See Miller V. Alabama, 567 U.S. 460 (2012). He is, of course, eligible for life imprisonment with the possibility of parole. 
should consider taking the actions I specify. ${ }^{4}$

In Part 2 of the essay, I clarify the concept of prevention. Deterring someone from committing a particular act is one way, though not, of course, the only way, of preventing it. In Part 3, I clarify the concept of deterrence. In Part 4, I analyze the concept of punishment and describe various modes of punishment. If we are serious about preventing school shootings and other mass homicides, then we must not rule out any mode of punishment a priori. That a particular mode of punishment (such as torture ${ }^{5}$ or hard labor) is no longer used, or has never been used (such as denying prisoners access to the Internet) is no reason to rule it out as a possibility. There are innocent lives at stake. In Part 5, I suggest some punishments that may deter would-be mass murderers. The aim is to find a punishment that the prospective murderer fears more than death. In Part 6, I suggest the inculcation of theism (understood as belief in a retributive god) as a means of deterring mass homicides. The fear in question is other-worldly (namely, divine retribution) rather than worldly (secular punishment), but there is reason to believe that it has been-and will continue to be-effective. In Part 7, I take up the topic of vicarious liability, or liability (civil or criminal) for the acts of others (such as one's children). I argue that this is an effective way to prevent school shootings. The person being deterred is not the prospective murderer himself or herself, but someone who has control over, or influence on, him or her. In Part 8, I consider three objections to my analysis, to each of which, I believe, there is an adequate reply.

\section{The Logic of Prevention}

General prevention ought to be the chief end of punishment, as it is its real justification. If we could consider an offence which has been committed as an isolated fact, the like of which would never recur, punishment would be useless. It would be only adding one evil to another. But when we consider that an unpunished crime leaves the path of crime open, not only to the

${ }^{4}$ This essay is a Nozickian explanation rather than an argument or proof. A philosophical explanation has the form, "how is one thing possible, given (or supposing) certain other things?" (Nozick, 1981: p. 9). For example, "How is it possible for us to have free will, supposing that all actions are causally determined?" and "[H]ow is evil possible, supposing the existence of an omnipotent omniscient good God?" (Nozick, 1981: pp. 8, 9). My question is this: "How is it possible to deter someone from committing a crime (such as murder), given that he or she is willing (even eager) to die?" Answering this question requires-among other things-an analysis of the concept of deterrence. ${ }^{5}$ The word "torture," like many other English words, has both descriptive and emotive meanings. Its emotive meaning is negative. I use the word descriptively in this essay, to mean "the action or practice of inflicting severe pain on someone as a punishment or to force them [sic] to do or say something, or for the pleasure of the person inflicting the pain" (New Oxford American Dictionary, 2010: p. 1829). (Compare Bentham's definition: "In its most extended sense, it [viz., the term "torture"] is employed to designate pain, especially pain of body, when considered as being intense in its degree, and this without reference to the cause by which it is produced" [Bentham, 1843: p. 393].) Strictly speaking, torture is the infliction of severe pain (not merely pain) on a sentient being. (Non-human animals can be tortured.) The first definition provided, which reports how the word is used by English-speaking Americans as of 2010, lists three purposes of torture, which we may call punitive, interrogational, and sadistic. This essay concerns only the first of these. I have nothing to say about interrogational or sadistic torture (from which it follows that I neither defend nor endorse them). 
same delinquent, but also to all those who may have the same motives and opportunities for entering upon it, we perceive that the punishment inflicted on the individual becomes a source of security to all (Bentham, 1843: p. 396).

In ordinary English, to prevent is to "keep (something) from happening or arising" or to "make (someone or something) unable to do something" (New Oxford American Dictionary, 2010: pp. 1384-1385). Implicit in this definition is the assumption that if one does not act, then the event in question will occur. To put it formally:

Subject S prevents event $e$ if and only if 1) S acts, 2) $e$ does not occur, and 3)

had $\mathrm{S}$ not acted, $e$ would have occurred.

Most acts of prevention are designed to keep bad things (as opposed to good or indifferent things) from happening. Among these bad things are death (or rather, since death is inevitable, premature death), disease (e.g., obesity, alcoholism, cancer, diabetes, tooth decay), injury (concussions, shin splints, broken bones), and crime (rape, drunk driving, murder). Crime prevention takes various forms, depending on how it operates on desire. We prevent crime (or try to) by 1 ) rehabilitating, 2) incapacitating, and 3) deterring. Rehabilitation is a type of manipulation. Incapacitation is a type of force. Deterrence is a type of coercion. Manipulation, force, and coercion are the three main ways in which human beings accomplish their (social) objectives, with a fourth (not applicable here) being rational persuasion.

To show how rehabilitation, incapacitation, and deterrence differ from one another, imagine someone who is bent on committing a particular crime, i.e., who has a desire (perhaps a strong one) to commit a particular crime. If authorities do nothing, the person in question will act on the desire and, if all goes well for him or her, commit the crime. Rehabilitation works by eliminating or extinguishing the desire. Incapacitation works by making the desire ineffective. Deterrence works by supplying a countervailing desire that overwhelms the desire to commit the crime. ${ }^{6}$

Let us take these forms of crime prevention in turn, beginning with rehabilitation. To rehabilitate, etymologically, is to make able again. Suppose authorities ${ }^{6}$ Here is how Bentham distinguishes the three forms of crime prevention:

With respect to a given individual, the recurrence of an offence may be provided against in three ways:-

1. By taking from him the physical power of offending.

2. By taking away the desire of offending.

3. By making him afraid of offending.

In the first case, the individual can no more commit the offence; in the second, he no longer desires to commit it; in the third, he may still wish to commit it, but he no longer dares to do it. In the first case, there is a physical incapacity; in the second, a moral reformation; in the third, there is intimidation or terror of the law (Bentham, 1843: p. 396).

Bentham's terms for rehabilitation are "amendment" and "reformation." His terms for incapacitation are "disablement" and "incapacitation." His terms for deterrence are "determent" and "intimidation" (Bentham, 1843: pp. 392, 396). 
have in their custody someone who has already broken the law. Various things may be done to (or for) this person to eliminate whatever residual desire there may be to commit further crimes (upon release). First, the person may be treated for physical or mental diseases or ailments. Second, the person may be trained in a craft, occupation, or profession, so that, upon release, he or she will be able to earn a living without having to resort to crime. Third, the person may be provided an education at taxpayer expense. Sex offenders may be castrated as a way to reconfigure their desires. The idea is to "remake," "rebuild," or "reform" the person by eliminating (or at least reducing the strength of) any desire he or she has to engage in criminal conduct. ${ }^{7}$ The person in question is like putty in the authorities' hands, which explains why this is a form of manipulation. ${ }^{8}$

To incapacitate, etymologically, is "to deprive of capacity" or "render incapable" (The Compact Edition of the Oxford English Dictionary, 1971: p. 1399). The most effective way to deprive someone of the capacity to commit a crime is to kill him or her. Dead people don't act; a fortiori, dead people don't commit crimes. Another way to incapacitate is to incarcerate, which, while effective in preventing crimes against those outside the facility, may not be effective in preventing crimes against those inside the facility, such as wardens, visitors, employees, and other inmates. (This is why solitary confinement is sometimes necessary.) Bodily constraints of various sorts, such as shackles, fetters, handcuffs, straitjackets, and leg irons, are other forms of incapacitation, as is amputation of limbs (such as the hands of thieves). The objective is to render any lingering criminal desire ineffective. We simply eliminate (or reduce) the power (or opportunity) to commit a crime. Since no attempt is made by authorities either to eliminate anti-social desires (manipulation) or to give the person in question countervailing desires (coercion), this mode of crime prevention is best categorized as force. People who can't be reasoned with, rehabilitated, or deterred must be incapacitated (like wild animals) by being taken off the streets. ${ }^{9}$

\section{The Logic of Deterrence}

Expertise [in coercing] is a matter of finding a particular sort of pain, menace, disorientation, insecurity, that will make an option unacceptable [to the person coerced] ... (O’Neill, 1991: p. 188).

\footnotetext{
"Rehabilitation seeks to instill in the offender the will to lead a good and useful life as defined by the social rules and conventions of the time. Rehabilitation, by definition, means to restore another to privileges, reputation, or proper condition; it means to restore to effectiveness or normal life by training" (Graydon, 1999: p. 731).

${ }^{8}$ The word "manipulate" derives from the Latin manus, meaning hand. See Oxford American Dictionary and Language Guide (1999: p. 605, s.v. "manual").

"Incapacitation is the idea of simple restraint: of rendering a convicted offender incapable, for a period of time, of offending again. Whereas rehabilitative and deterrent strategies seek to make the offender less criminally inclined, incapacitation presupposes no such change. Instead, obstacles are interposed to impede the person's carrying out whatever criminal inclinations he or she may have. Usually, the obstacle is the walls of a prison, but other incapacitative techniques are possible, such as exile or house arrest" (Von Hirsch, 1999: p. 395).
} 
The third form of crime prevention (besides rehabilitation and incapacitation) is deterrence. To deter, etymologically, is to frighten away from. Deterrence works only on rational beings, for it requires practical reasoning. (Non-human animals, being non-rational, cannot be deterred, though they can be trained, conditioned, or incapacitated.) When the state prohibits a given act, it says, in effect: "Don't perform this act, or else." The "or else" specifies a punishment. The aim is not to eliminate or extinguish a desire to commit a crime (as in the case of rehabilitation); nor is it to make such a desire ineffective (as in the case of incapacitation). It is to overwhelm the desire by giving the person in question a countervailing (i.e., even stronger) desire not to commit the crime. Here is how a deterred person reasons:

1) I desire to do act $A$, but

2) If I do A, then I am likely to be punished for it.

3) Since I desire not to be punished even more than I desire to do A,

4) I shall refrain (grudgingly) from doing A. ${ }^{10}$

Desires have the property of strength, meaning that some are stronger than others. Other things being equal, the stronger the desire to act, the more severe the punishment must be in order to overwhelm it. If I have a strong desire to do act A, then it will take a severe punishment (by my lights) to deter me. If I have only a weak desire to do act $\mathrm{A}$, then a comparatively mild punishment may suffice.

People are deterrable to different degrees. Some people (let us call them "undeterrables") are not deterrable at all, for they are indifferent to their own punishment. Just as rehabilitation and incapacitation can fail, so too can deterrence. Effective deterrence requires calibration, by the authorities, of both 1) the strength of the desire to commit a crime and 2) the type or severity of punishment to be meted out for successful commission of the crime.

Deterrence is a triadic relation. The first place of the relation is filled by the individual (the "deterrer") who does the deterring. The second place is filled by the person (the "deterree") who is (to be) deterred. The third place is filled by the act the deterree is being deterred (by the deterrer) from performing. Formally: ' $\mathrm{x}$ deters $\mathrm{y}$ from doing $\mathrm{z}$ '. Deterrence works by means of a threat. I threaten you with harm if you do $\mathrm{z}$ (or, in the case of requirements, don't do z) ${ }^{11}$ Deterrence is a form of coercion. Whether the coercion is justified is a question of moral or political philosophy that is beyond the scope of this essay. I assume in what follows that the coercers (i.e., the deterrers) are public authorities acting 10"To deter someone (at least the rational actor of decision theory), one would have to threaten to make that person suffer or at least make things less pleasant than they were before" (Child, 1999: p. 202).

${ }^{11}$ Prohibitions have the form, 'Don't do z or else'. Requirements have the form, 'Do z or else'. Let us call the former "negative coercion" and the latter "positive coercion." Deterrence is negative coercion We might also distinguish between (1) public authorities acting within the scope of their authority and (2) other authorities (such as parents) or individuals (such as robbers). These distinctions cut across one another, creating four jointly exhaustive and mutually exclusive categories: (i) positive coercion by public authorities; (ii) positive coercion by other authorities or individuals; (iii) negative coercion by public authorities; and (iv) negative coercion by other authorities or individuals. Bentham's main concern in "Principles of Penal Law" is category iii; O'Neill's main concern in the essay cited above is category ii. 
within the scope of their authority and that the individuals to be coerced (i.e., the deterrees) are individuals who are subject to, or within the jurisdiction of, the criminal law.

\section{Modes of Punishment}

Let us define "punishment" as the deliberate (not merely intentional) infliction of harm, or denial of a benefit otherwise due, by an authority (civil, parental, military, ecclesiastical, or pedagogical), for a supposed offense (rule-violation, norm-transgression). ${ }^{12}$ This definition allows for the possibility of unjust punishment-as, for example, where an innocent person is thought by authorities to have committed a crime. Let us confine ourselves in what follows to civil punishment, in which the authorities in question are agents of the state acting under color of law in behalf of the citizenry.

The harm or harsh treatment being meted out as punishment may take any of several forms. If we think of harm as "the thwarting, setting back, or defeating of an interest" (Feinberg, 1984: p. 33), then the question arises as to what interests individuals have. Without attempting to be comprehensive, we can say that the main interests possessed by normally functioning human beings are:

1) Bodily integrity (which includes the avoidance of pain or discomfort);

2) Liberty (understood negatively as the absence of constraint);

3) Property (real or personal, tangible or intangible); and

4) Reputation (understood as status or standing in the community).

Let us call the invasion of bodily integrity "corporal punishment." Corporal punishment is either capital or non-capital, depending on whether the offender is put to death. (All capital punishment is corporal, but not all corporal punishment is capital.) Deprivation of liberty is confinement, incarceration, or imprisonment. Deprivation of property (via fine or forfeiture) is pecuniary punishment. Deprivation of reputation or status is a form of shaming or stigmatization. A given individual may, of course, be punished in more than one of these ways for the same offense. For example, one may be incarcerated and fined for driving while intoxicated. ${ }^{13}$

If we are serious about preventing school shootings and other mass homicides, then we will not rule out any of these punishments a priori. We may well decide that certain modes of punishment are too costly, given the expected benefits to be derived therefrom, but this will be the result or reasoning or deliberation, not fiat. In other words, we will have decided that the expected costs of inflicting a certain type of punishment (such as severe and prolonged bodily pain) are greater than the expected benefits of preventing mass murder. ${ }^{14}$

\section{How to Deter Mass Murderers}

That it should enter into the heart of an Englishman to harbour a single

${ }^{12}$ Compare Bentham's crisp definition: "Punishment may be defined-an evil resulting to an individual from the direct intention of another, on account of some act that appears to have been done, or omitted" (Bentham, 1843: p. 390). 
word in favour of a practice [viz., torture] abolished within a few years in several of the most absolute governments in Europe, may of all things seem singularly strange and unexpected. But in the course of a scrupulous examination a man learns to render himself proof against the delusive power of words, and to correct the first impressions of sentiment by the more extensive considerations of utility (Bentham, quoted in Twining \& Twining, 1973: p. 308). ${ }^{15}$

Most people, fortunately, need no incentive to refrain from murdering. It never crosses their minds to kill someone; or, if it does, the thought is quickly ${ }^{13}$ Volume 1 of Bowring's edition of Bentham's Works contains, among other tracts or treatises, "Principles of Penal Law," which has three parts: "Political Remedies for the Evil of Offences," "Rationale of Punishment," and "Of Indirect Methods of Preventing Crimes." "Rationale of Punishment" comprises six books: "General Principles," "Of Corporal Punishments," "Of Privative Punishments, or Forfeitures," "Of Mis-Seated Punishment," "Of Complex Punishments," and "Miscellaneous Topics."

Every punishment, Bentham says, is either corporal or privative, depending on whether it "immediately affect $[\mathrm{s}]$ the person in its $[$ sic] active or passive powers" (corporal) or "deprive[s] the individual of some advantage which he before enjoyed" (privative). Bentham distinguishes five types of corporal punishment (which is treated in Book II of "Rationale of Punishment"): simply afflictive (treated in Chapter I, pages 413-416), complexly afflictive (Chapter II, pages 416-420), restrictive (Chapters III-IX, pages 420-437), active or laborious (Chapter X, pages 437-441), and capital (Chapters XI-XII, pages 441-450). Privative punishments (treated in Book III of "Rationale of Punishment") are distinguished by what is taken away: either property (Chapter IV), reputation (Chapter III), or condition (Chapters V-VI).

Afflictive punishments are designed to produce suffering. If the suffering is immediate and temporary, the punishment is simply afflictive; if it is more permanent ("distant and durable"), it is complexly afflictive. Examples of the former include whipping, picketing, and ducking. Examples of the latter include branding, tattooing, and mutilation. Restrictive punishments "are those which restrain the faculties of the individual, by hindering him from receiving agreeable impressions, or from doing what he desires; they take from him his liberty with respect to certain enjoyments and certain acts" (Bentham, 1843: p. 420). Examples include imprisonment, relegation (to a particular part of the country), and banishment (from the country). Active or laborious punishments are those which are "inflicted on a man by obliging, or, to use another word, compelling him to act in this or that particular way; to exert this or that particular species of action" (Bentham, 1843: p. 437). Capital punishments are those that produce death. Simple capital punishments are those that produce death with no more pain than is necessary to bring about death. Examples include hanging and beheading. Afflictive capital punishments are those that (by design) produce death with more pain than is necessary to bring about death. Examples include crucifixion, "exposure to wild beasts," burning, "empaling," tearing to pieces, and breaking on the wheel (Bentham, 1843: p. 442).

${ }^{14}$ Bentham rejected all-or-nothing approaches to punishment. With regard to torture, for example, he wrote: "Torture, by many of those who have sitten in judgement over it, seems to have been regarded in one single point of view, as if it were one single individual thing, applied constantly to one and the same purpose. Those who viewed it in this light which ever part they take, whether they approve it, or whether they condemn it, can not fail of being mistaken. On this subject as much as on most others it behoves us to be on our guard not to be led astray by words. There is no approving it in the lump, without militating against reason and humanity: nor condemning it without falling into absurdities and contradictions" (Bentham, quoted in Twining \& Twining, 1973: p. 337). The manuscript being quoted is entitled "Of Compulsion and Herein of Torture." It is in the Bentham Papers at University College, London.

${ }^{15}$ The manuscript from which this passage is taken is entitled "Of Torture." It is in the Bentham Papers at University College, London. In the paragraph previous to the paragraph being quoted, Bentham wrote: "If a few years ago any one had foretold to me that in any case I should be in the least disposed to approve of any thing to which the name of Torture could with any sort of propriety be applied, I should have thought he had done me great Injustice" (Bentham, quoted in Twining \& Twining, 1973: p. 308). 
and easily banished. Most people who desire to commit murder are deterrable (i.e., capable of being deterred) by the prospect of death (as punishment). This is because, for most people, death-by which I mean physical annihilation-is the worst misfortune that can befall them. ${ }^{16}$ However, some people who desire to commit murder are undeterrable by the prospect of death. Indeed, as we saw, some people who plan mass murder intend to kill themselves when their murderous acts are completed. What, if anything, can be done to deter these individuals? The short answer is that they must be threatened with something worse than death, or rather, with something that they view as worse than death.

What might that something be? Some suicidal mass murderers may be deterred by the thought of an ignominious or infamous death. The death itself may not be feared, but if the death is brought about in a publicly disgraceful, shameful, or humiliating way, it may act as a deterrent. This is particularly likely to be the case with disaffected adolescent murderers, some of whom harbor fantasies of posthumous fame or glory. Thinking that their lives are unknown, undistinguished, and meaningless, they set out to achieve notoriety, and even, in their twisted minds, celebrity, by doing something spectacular (even if spectacularly evil). Many recent school shooters have had their likenesses displayed on television for days on end, with nauseating commentary by reporters and analysts on every aspect of their lives, including what they posted on their social-media accounts, how they dressed, what their hobbies were, which political parties, candidates, or causes they supported, and what music they listened to. ${ }^{17}$ What better way to counteract this desire than by threatening ignominious death, which combines capital punishment with stigmatization (i.e., loss of reputation)? ${ }^{18}$

Related to this mode of punishment is the manner of bodily disposal following death. At one time, suicides were denied Christian burial. Some of them were buried at a crossroad with a stake driven through their hearts (see, e.g., Bur-

\footnotetext{
${ }^{16} \mathrm{Kant}$ appears to agree with this, for he is reported by a student as saying: "All cruel tortures are ... needless, for since death is the most dreadful, it may be assumed that anyone undaunted by capital punishment is also superior to all other torments as well" (Kant, 1997: p. 311; ellipsis added).

${ }^{17}$ The authors of a recent book about the effects of video games on adolescents refuse to mention the names of killers in Orlando, Columbine, Virginia Tech, Aurora, Sandy Hook, Isla Vista, Charleston, and San Bernardino, on the ground that "They [the killers] committed their mass murders in order to gain fame, and we will not give it to them." Instead, the authors list the names and ages of the 26 victims of the Sandy Hook murderer. "Each [victim] was filled with infinite potential, treasures of immeasurable value to their loved ones. Their lives were stolen, their potential destroyed, lost to us all forever" (Grossman, Paulsen, \& Miserany, 2016: pp. 209-210).

${ }^{18}$ Sir William Wallace (c. 1270-1305), leader of the Scottish resistance against King Edward I of England, was found guilty of treason. As punishment for this crime, he was throttled (at the end of a noose), emasculated, eviscerated, decapitated, and quartered. "His head was exhibited upon a spike on London Bridge" and the four pieces of his corpse were "sent for public display in Newcastle, Berwick, Stirling and Perth" (Oliver, 2010: p. 117). It might be said that this death was not stigmatizing, since Wallace was (and is) a national hero in Scotland. It might even be said that Wallace's ignominious death contributed to his heroic status. I admit the possibility that certain school shooters, if put to death in an ignominious fashion, will become "heroes" to mentally unstable individuals; but this is likely to be the case with any punishment, even life imprisonment with the possibility of parole. In other words, I don't think that this is an argument against ignominious death per se.
} 
gess-Jackson, 1982: p. 80). The more gruesome the manner of disposal, the more fear or distaste it may strike into the heart of a prospective murderer. For it is one thing to imagine oneself a celebrity or a hero as a result of one's mass homicide. It is quite another to think that one will be belittled by those one had hoped to impress. What are these methods of bodily disposal except measures designed to generate mockery, scorn, and contempt?

Let us turn from capital to non-capital corporal punishment. The law may say to prospective mass murderers that if they survive their killing sprees, whether by design or by accident, they will be tortured. ${ }^{19}$ The torture-a combination of incarceration (deprivation of liberty) and corporal punishment (invasion of bodily integrity) - may take any of a variety of forms, but it will involve the infliction of severe, and in some cases excruciating, pain. The pain (Bentham's "affliction") may be inflicted only once or at regular intervals. Even people who have no fear of their own annihilation may fear being tortured as punishment for their crimes. This explains the saying "Better dead than ...," where the ellipsis is filled in differently by different people. The law can take advantage of this widespread sentiment by threatening the infliction of severe pain. ${ }^{20}$

With regard to the deprivation of liberty by means of incarceration, there are possibilities beyond merely locking someone up and throwing away the key. An adolescent school shooter, for example, may be a devotee of social media, an aficionado of video games, or an avid user of the Internet. For these individuals, a life without Internet access or the use of social media may be a fate worse than death. The law might threaten to deprive mass murderers of Internet access for the rest of their lives. It is no objection that this will not deter everybody. No punishment deters everybody. The goal is to deter at least some of those who are bent on massacre. Each mass murderer deterred, after all, spares (by definition) two or more innocent lives. ${ }^{21}$

Finally, let me mention a type of punishment that was once widely used but has fallen into disfavor: hard labor, or what Bentham called "active or laborious punishment.” This punishment, like torture, combines incarceration (deprivation of liberty) with invasion of bodily integrity. The mass murderer would not be allowed to languish in prison, whiling away the hours, days, weeks, months, and years; he or she would be made to work, preferably (for maximum deterrent effect) at an onerous, dirty, menial-perhaps even dangerous—-task. How many

\footnotetext{
${ }^{19}$ Stephen Kershnar (1997-1998) has argued in favor of torture as punishment on retributive grounds, i.e., on grounds that certain convicted criminals, such as "multiple murderers," deserve to be tortured. "Torture," he writes, "can take many forms, ranging from mild tortures, such as sleep deprivation, physical isolation, physical shaking, to more severe tortures, such as bodily mutilation, electric shock, and invasion of bodily orifices with physical objects" (Kershnar, 1997-1998: p. 497). $M y$ argument for the use of torture-remember that the argument is conditional in nature-is consequentialist (forward-looking) rather than retributive (backward-looking), in that its aim is general deterrence rather than payback. This is not to say that I think school shooters do not deserve to be tortured. Many of them clearly do.

${ }^{20}$ It might be argued that this only ensures that the shooter will commit suicide. But that supports my argument, for it shows that severe or excruciating pain is feared more than death.

${ }^{21}$ Since this punishment deprives the culprit of an advantage otherwise present or due, it constitutes what Bentham called a "privative," as opposed to a "corporal," punishment.
} 
adolescent shooters want to spend the rest of their lives on a chain gang? How many of them want to break rocks, work on an assembly line, scrub floors, wash dishes, harvest crops, clear brush, or pick up trash along roadways? One suspects that many of them would view such a prospect with horror, which is, of course, the point.

I have chosen not to go into much detail in describing these punishments. There is no need to be specific. ${ }^{22}$ The point is that, in order to deter people who are not afraid to die, and especially those who are eager to die, the authorities must be bold and creative. They must threaten something that is feared, by the perpetrator, more than death. ${ }^{23}$ What this is will vary by person, so legislation must allow judges significant sentencing discretion. ${ }^{24}$

\section{Inculcating Theism}

The considerations derived from the religious sanction, are the sufferings apprehended from the immediate will of the Deity, in some degree perhaps in the present, but chiefly in a future life. This displeasure is, under the Christian religion, and particularly the Protestant, invariably believed to be annexed, with few or no exceptions, to all those malpractices which bring men into prisons. The considerations, therefore, which that sanction affords, are to be numbered among the considerations which tend to restrain men from committing crimes (Bentham, 1843: p. 429; italics in original).

To this point in the essay, I have discussed only worldly (mundane) punishments. I have argued that, since some (perhaps many) mass murderers have little or no fear of death, society must employ something other than (or in addition to) capital punishment if it hopes to deter them. Let us turn now to eternal (transcendent) punishments. Suppose a prospective school shooter finds his or her life meaningless, worthless, or just plain boring and wants to go out in a "blaze of glory" by killing many innocent people prior to killing himself or herself (or being killed by security guards, police officers, or civilians). The shooter in question not only doesn't intend to survive; he or she intends not to survive.

If death is viewed by this person as nothing more (or less) than physical annihilation, then he or she is undeterrable, for annihilation is, by hypothesis, de${ }^{22}$ Anyone who wishes to have more detail should consult Bentham's "Principles of Penal Law."

${ }^{23}$ I assume that nobody-certainly no reader of this journal-thinks that mass murderers should be punished with less than life imprisonment with the possibility of parole. In other words, everybody believes that mass murderers deserve, at a minimum, to spend their lives in prison (with the possibility of parole). The problem is that some or many mass murderers are not afraid either to die or to spend their lives in prison (with or without the possibility of parole). In order to deter such people, therefore, we will have to add something to life imprisonment or death. I have suggested that life imprisonment be conjoined with pain, hard labor, or denial of Internet access (or some combination of the three). I have also suggested that death be conjoined with pain or ignominy (or both).

${ }^{24}$ It might be said, by way of objection, that judges already have such discretion. They do not. In Texas, for example, the punishment for capital murder (defined at Tex. Penal Code $\$ 19.03$ ) is either “imprisonment ... for life without parole or ... death." Tex. Penal Code $\$ 12.31(\mathrm{a})$. No other punishment, such as torture, ignominious death, ignominious burial, hard labor, or denial of Internet access, is permitted. It will therefore take legislation, and perhaps constitutional amendment, to implement my suggestions. 
sired rather than feared. But what if physical annihilation is not viewed by this person as his or her end, or fate? What if the shooter believes, instead, that there is a significant probability, or even a mere logical possibility, of personal survival of bodily death? Is he or she willing to risk eternal punishment at the hand of a just god (for surely a just god will not look kindly on the massacre of innocents)? Annihilation is one thing; everlasting torment ("hellfire and brimstone," eternal damnation) quite another.

If what I am suggesting is correct, i.e., if there are individuals who are deterrable by eternal punishments but not by worldly punishments, then society has a strong interest in inculcating theism, by which I mean belief in a retributive god-a god who rewards and punishes moral agents in proportion to their earthly deserts. ${ }^{25}$ It is often said ${ }^{26}$ that belief in such a deity has been in decline for several centuries, and that this has had profound effects, both good and bad, on society. If the decline in theism were irreversible, then this line of thought would be unpromising. But what if the decline is reversible? What if individuals can be brought to believe in a loving but stern god who will punish them for their earthly misdeeds? It is worth thinking about how this might be accomplished, especially since, if it can be accomplished, there will (almost certainly) be fewer massacres of innocents.

One way to inculcate theism is to require, by law, the daily recitation of an official state prayer in public schools. The Supreme Court of the United States has ruled that such a requirement violates the First and Fourteenth Amendments of the Constitution, ${ }^{27}$ but Supreme Court cases can be (and sometimes $\operatorname{are}^{28}$ ) overruled, and the Constitution itself can be (and has been) amended. It would be folly to think (or claim) that everyone made to recite prayers in school (or elsewhere) will become a theist, but there is reason to believe that some will, and this may be enough to prevent a mass homicide or two, or three. We must not forget that even one mass homicide prevented means (by definition) the saving of two or more precious lives. One of these lives may be your own, or that of your child, neighbor, friend, or colleague.

Mandatory prayer is not the only way to inculcate theism, especially since it runs up against strong opposition. Another way is to mandate, or perhaps merely to encourage and to subsidize, the teaching of courses about religion. Ernest Boyer concludes a thoughtful essay with the following plea:

\footnotetext{
${ }^{25}$ Bentham wrote that there are four "sources of pain and pleasure," which he called "sanctions." The sanctions are physical, political, moral, and religious. The "political magistrate," he says, must not leave the religious sanction out of his or her calculations. See Bentham, 1996: chap. III.

${ }^{26}$ By, e.g., the philosopher Walter Stace. See Stace, 1948.

${ }^{27}$ See Engel v. Vitale, 370 U.S. 421 (1962). The Court has also struck down (on the same grounds) a requirement "that passages from the Bible be read or that the Lord's Prayer be recited in the public schools of a State at the beginning of each school day-even if individual students may be excused from attending or participating in such exercises upon written request of their parents." See Abington School District v. Schempp, 374 U.S. 203 (1963).

${ }^{28}$ See, e.g., Lawrence v. Texas, 539 U.S. 558 (2003), which overruled Bowers V. Hardwick, 478 U.S. 186 (1986).
} 
It's an absolute imperative ... that public education remain free of sectarian control and that the conscience of every student be vigorously affirmed. At the same time, students should surely study about religion and its influence throughout history. They should understand that the search for meaning is universal and that religion has profoundly shaped the human experience on this planet (Boyer, 1992: pp. 523-524; ellipsis added).

Boyer recommends that "the sacred texts of all the great religions ... be introduced to students with reverence and intellectual insight" (Boyer, 1992: p. 517; ellipsis added). ${ }^{29}$ Though the aim of such an approach is not to indoctrinate, in the sense of putting a doctrine (namely, theism) into students, it may well result in some of the students-those who might otherwise remain oblivious to the history and teachings of religion-coming to believe in God. This, in turn, may have a deterrent effect on those among them who are tempted to commit crimes such as murder.

If there are other ways to reverse the decline in religious belief, then we have reason to consider, and perhaps to implement, them. Other things being equal, the more people who believe in a retributive god, the fewer school shootings and other mass homicides there will be-indeed, the fewer crimes there will be. For God, if there is a god, knows everything, even one's beliefs, motives, and intentions, and there is no escaping God's justice. ${ }^{30}$

\section{Vicarious Liability}

Our discussion to this point has focused on deterrence rather than incapacitation or rehabilitation, though all three of these, as we saw earlier, are forms of (crime) prevention. One reason for this limitation is that rehabilitation requires that the person in question be in custody. How do we prevent people who are not in custody, and have never been in custody, from committing mass murder? As for incapacitation, one cannot take away another's power to act unless one knows who is likely to act. By all accounts, nobody knew that the Santa Fe shooter intended to commit his horrific crimes. Deterrence, to be effective, requires neither custody of the culprit nor knowledge of his or her intentions. The idea is to threaten everyone, and therefore, eo ipso, those who have evil designs.

So far, we have been discussing deterrence of the prospective murderers themselves, but there are others who might be deterred by either the threat of criminal punishment or the prospect of civil liability. Vicarious liability is "Indi-

\footnotetext{
${ }^{29}$ For a discussion, by a prominent constitutional theorist, of the constitutionality of teaching about religion in public schools, see Greenawalt, 2005: esp. pp. 19, 41, 85, 127, 142, 149, 150-151, and 186. Greenawalt quotes the majority opinion in Abington School District v. Schempp (the Bible-reading case cited above) as saying, "[I]t might well be said that one's education is not complete without a study of comparative religion or the history of religion and its relationship to the advancement of civilization. It certainly may be said that the Bible is worthy of study for its literary and historic qualities. Nothing we have said here indicates that such study of the Bible or of religion, when presented objectively as part of a secular program of education, may not be effected consistently with the First Amendment" (Greenawalt, 2005: p. 19; brackets in original).

30"'God's justice is the precise allocation of punishments and rewards in accordance with men's good or bad behaviour" (Kant, 1997: p. 114).
} 
rect legal responsibility; for example, the liability of an employer for the acts of an employee, or, a principal for torts and contracts of an agent" (Black's LaW Dictionary, 1979: p. 1404). Perhaps society should hold guardians and parents legally responsible for the crimes of their wards and minor children, respectively. ${ }^{31}$ The responsibility may be either criminal or civil. If civil, it may be either strict or non-strict. Strict liability is liability without fault. It is traditionally reserved for activities that are inherently dangerous, such as blasting (with explosives) on one's property. Non-strict liability is fault-based, which means that you are liable only if you are at fault in some way. If you can show that you took reasonable precautions against harm, then you are absolved of legal responsibility for the harm caused.

The Santa Fe shooter used his father's guns to commit his murders. Perhaps society should threaten gun owners with civil liability for all harms committed with their guns. (In order to ensure adequate funds to pay damages, the law might require liability insurance for gun owners, in the same way that it requires liability insurance for automobile drivers.) If guns are inherently dangerous, in the way that explosives are inherently dangerous, then perhaps this liability should be strict. Society would be telling gun owners that if their guns are used in the commission of a crime, then they are liable for damages to the victims, even if they took reasonable precautions against theft or misuse. If this is too strong to be palatable, then society may tell gun owners that they are liable if (and only if) they are negligent.

The idea in both cases is to deter someone besides the prospective murderer-someone who has, or, more precisely, someone who is presumed by law to have, control over (or influence on) him or her. As for how this works, it depends on what the guardian or parent does to prevent harm. There are three possibilities. First, the guardian or parent may deter-by threatening harm (or denial of benefit) to the ward or child if he or she commits a crime. Second, the guardian or parent may incapacitate-by, for example, locking up the guns or other instrumentalities (such as bomb-making materials) that would otherwise

\footnotetext{
${ }^{31}$ Bentham calls this "substitutive satisfaction [or indemnification]," which he defines as "satisfaction at the expense of a third party; as when a person who has not committed a crime finds himself responsible in his fortune for him who has committed it" (Bentham, 1843: p. 372). According to Bentham, "a third person ought to be called upon to pay, instead of the author of the mischief, when he [the author] cannot furnish the satisfaction, and when the obligation imposed upon this third party tends to prevent the offence" (Bentham, 1843: p. 383).

Bentham's examples include responsibility of a master for his servant, a guardian for his ward, a father for his children, a widow for her children, a husband for his wife, and "an innocent person, who profits by the offence" (Bentham, 1843: p. 383; see also Bentham, 1843: p. 478). The rationale for holding a father responsible for the "faults" of his children is that "the father, who might have fashioned at his own will the character and the habits of his children, may be considered the author of all the dispositions which they manifest. Are they depraved? it is almost always the effect of his negligence or of his vices. He ought, therefore, to bear the consequences of an evil which he ought to have prevented" (Bentham, 1843: p. 385).

A father's legal responsibility ends when the minor reaches the age of majority, for "He [the father] ought no longer to bear the punishment of an action which he has no longer the power to hinder" (Bentham, 1843: p. 385).
} 
be used to commit a crime. Third, the guardian or parent may rehabilitate-by so educating the ward or child that he or she no longer has anti-social desires. Most parents take moral instruction of their children seriously, for entirely legitimate, other-regarding reasons, such as love. The state has the power to make moral instruction a matter of parental self-interest. The state says, in effect, "Control your children, or else."

\section{Objections and Replies}

Let us turn to some objections. It will be said, at the outset, that I am ignoring the elephant in the room. If our aim is to prevent school shootings, then why not confiscate (i.e., why not ban the private ownership and possession of) firearms? If there are no guns, then, a fortiori, there will be no school shootings. It will not do to reply to this objection that the Supreme Court has interpreted the Second Amendment so as to confer on individuals a right, unrelated to their participation in a militia, to own and possess firearms, ${ }^{32}$ for we saw in connection with school prayer that 1 ) the Court can (and sometimes does) overrule its previously decided cases and 2) the Constitution can be (and has been) amended. What the law is and what it should be are separate questions. This essay is about what the law should be-if, at any rate, we wish to prevent school shootings and other mass homicides.

The first thing to be said in reply to this objection is that there are other ways to commit mass murder besides shooting. In recent years, unfortunately, we have seen mass murders committed by bombing, by stabbing or slashing, ${ }^{33}$ and by driving motor vehicles into crowds. (There are, of course, many other ways to massacre human beings, such as by poisoning and, as in the attacks of 11 September 2001, by flying airplanes into buildings.) It is a sad fact of life that people who are bent on mass murder will find ways to accomplish their nefarious goals. Confiscation of firearms is a form of incapacitation. It does not, in itself, eliminate the desire to kill, so it is not a form of rehabilitation. Nor does it give the prospective murderer a self-interested reason not to kill, so it is not a form of deterrence. All it does is eliminate the power to kill by shooting, it does not eliminate (though it may significantly reduce) the power to kill.

I have not mentioned the fact that confiscation of guns by authorities is unlikely to be successful, given human nature. Law-abiding citizens may turn in their weapons if required by law to do so, but not all citizens are law-abiding. There will always be firearms in the hands of private citizens, even if such possession is prohibited by law and even if it is severely punished. (Murder occurs, after all, though it is prohibited and severely punished.) Someone who is determined to kill with a firearm will find a way to acquire such a weapon. I am not convinced, therefore, that the objection in question undermines my proposal. Something other than, or in addition to, confiscation of firearms will have to be ${ }^{32}$ See District of Columbia v. Heller, 554 U.S. 570 (2008), and McDonald v. Chicago, 561 U.S. 742 (2010).

${ }^{33}$ This is not as far-fetched as it may seem. See Gomez, 2018. 
tried in order to prevent school shootings and other mass homicides.

If this reply is felt to be unpersuasive, then I suggest that the reader bracket (i.e., set aside) the question of confiscation. My essay should be understood not as an exploration of all possible means of preventing school shootings, but (more narrowly) as an exploration of means other than the confiscation of firearms. The question I am asking is, "Suppose nothing can be done about the number or types of weapons in society; what else might be done to prevent school shootings?" Just as Judith Jarvis Thomson (1971) bracketed the question of fetal personhood in order to make progress on the question of the moral permissibility of abortion, I wish to bracket the question of the legitimacy of firearms confiscation in order to make progress on the question of how to prevent school shootings (and other mass homicides). The aim is to move the discussion forward, not remain mired in a debate that has been taking place with no resolution for many decades.

A second objection to my argument (remember that it is conditional in nature) is that some or all of the punishments I have recommended-ignominious death, ignominious burial, torture, and hard labor, to be specific-are barbaric, in the sense of "savagely cruel" or "exceedingly brutal" (New Oxford American Dictionary, 2010: p. 131). It took a long time (the critic says) for society to abolish these punishments, so they should not be revived, lest society regress to a condition of savagery. This objection must not be understood as relying on the Eighth Amendment, which prohibits "cruel and unusual punishments," for, as we have seen, 1) the Constitution can be amended and 2) Supreme Court cases interpreting the Eighth Amendment can be overruled. The objection is moral, not legal, in nature. It is about what the law should be, not what the law is.

The objection cannot be evaluated until it is clarified. I believe that once it is clarified (which includes having its implications drawn out), it will lose whatever plausibility it initially had. Let us focus on torture, for I find it hard to believe that anyone can hold that ignominious death, ignominious burial, or hard labor are (literally) barbaric. Many states already put murderers (or some subset thereof) to death as punishment for their crimes. Surely capital punishment per se is not barbaric. Ignominious death simply adds disgrace and shame to capital punishment. Ignominious burial cannot be cruel, much less savagely cruel, for it occurs after death, and dead people do not suffer or feel pain. Hard labor may be onerous, but it is undertaken voluntarily by many workers who are trying to support their families. These punishments may be objectionable, and perhaps unacceptable, all things considered, but it is difficult to believe that they are barbaric.

The objection, then, is that torture, as punishment, is barbaric, and therefore (presumably) morally impermissible. But this cries out for clarification. Does the critic mean to say that torture is barbaric only if it fails to deter, or that it is barbaric (and therefore morally impermissible) even if it deters? The former is an odd position to take, for why should a type of punishment be "savagely cruel" or "exceedingly brutal" only if it fails to deter? Does the fact that it deters make it less cruel or less brutal? I shall therefore interpret the objection as saying that 
torture is barbaric (and therefore morally impermissible) even if it deters. The next question is whether the amount of deterrence matters. Suppose a particular punishment deters (and is known to deter) hundreds of would-be murderers; would the critic say that it is no longer barbaric? That would be an odd position to take. Why should the amount of deterrence make a difference to the barbarity of the punishment? I assume, therefore, that the objection goes as follows: Torture is barbaric (and therefore morally impermissible) even if it prevents hundreds, thousands, or millions of murders. The critic, as this shows, is an absolutist about torture. Fiat justitia, ruat colum. ${ }^{34}$

We must now ask how personal desert bears on barbarity. Is the critic saying that torture is barbaric only if it is undeserved, or that it is barbaric even if it is deserved? The first of these is equivalent to saying that if torture is deserved in a given case, then it is not barbaric. While it is possible for someone to hold this view, I shall ignore it in what follows and assume that the critic means to assert the second proposition-that torture is barbaric even if it is deserved.

When we conjoin the two claims, we get this: Torture is barbaric (and therefore morally impermissible) even if 1) it prevents hundreds, thousands, or millions of murders and 2) it is deserved. Let us make the discussion concrete. Suppose Adolf Hitler had been taken alive following his atrocities. Suppose, furthermore, that torturing him would almost certainly have prevented hundreds of thousands of murders, by deterring like-minded, similarly situated individuals (i.e., genocidal potentates). Surely it cannot be said that Hitler didn't deserve to be tortured, given his heinous acts. Our critic is committed to saying in such a case that it would have been morally impermissible to torture Hitler, and would be just as impermissible today if a new Hitler emerged. The moral impermissibility of torture is, to the critic, categorical. It is wrong to torture, period; no ifs, ands, or buts. It is wrong to torture even if torture is necessary (because no other punishment deters) and sufficient (because it does deter) for the prevention of enormities such as that which occurred in Santa Fe, Texas.

It might be said that this scenario is far removed from school shootings; but is it? Do the numbers matter? In the typical school shooting, dozens of innocent people (often children) are shot, some of them in the stomach, chest, neck, back, or head. Some of the victims die instantly; others die slowly and painfully, with no loved ones around to comfort them. They die wondering what happened and what they did to deserve such a horrible fate. ${ }^{35}$ How can it be said that torture of the shooter in such a case is undeserved? He or she is the very personification of evil. If anything is deserved, torture of school shooters is deserved. We are assuming, moreover, that the act of torturing will deter like-minded, similarly situated individuals. The case of a school shooter, I submit, is structurally parallel to that of Hitler. Only the number of victims differs, and why should that make a moral difference?

34"Let right be done, though the heavens should fall" (Black's Law Dictionary, 1979: p. 561).

${ }^{35}$ For eyewitness accounts of the brutality and horror of the Santa Fe shootings, see Healy, Fernandez, \& Blinder 2018. 
Not everyone will be persuaded by my reply to this objection. When it comes to torture, absolutism is a popular position, even (especially!) among academics (see, e.g., Mayerfeld, 2008; Juratowitch, 2008; Shue, 2005; Waldron, 2005). Anyone who is open to the moral permissibility of torture, however (that is, anyone who is not an absolutist), should be open to my recommendation that school shooters and other mass murderers be tortured as a means of preventing similar incidents. Consequentialists, for example, should find the argument congenial. Even deontologists who are not absolutists (a Rossian pluralist, for example) should find it congenial.

Let me make a final comment on the barbarity objection. I have not, to this point in the essay, addressed the barbarity of not using torture and other punishments (such as hard labor) to deter school shootings. Suppose I concede, for the sake of argument, that these punishments are barbaric. That does not end the discussion; it only begins it. Isn't it just as barbaric, if not more so, to refrain from taking steps to prevent mass homicides? The choice is between 1) torturing duly convicted mass murderers and 2) allowing innocent people (including precious children) to die. If you believe that this is not the choice we face, then you must believe that torturing is ineffective as a deterrent. Do you have evidence for that belief, or is it an article of faith? Surely omissions, as well as actions, can be barbaric. Are we not as responsible, morally, for what we allow to occur as for what we do?

A third objection to my argument concerns the inculcation of theism. The critic will say that theism is false, or at least not known to be true, and that I am therefore advocating the inculcation, in impressionable young minds, of a false or unjustified belief. The first thing to be said about this objection is that it is, philosophically speaking, presumptuous. The critic does not know that there is no god, since there has never been a successful proof thereof. For all the critic knows, there is a retributive god of the sort I have discussed in this essay. ${ }^{36}$ And while the critic may believe that there is no justification for belief in god, many equally informed and intelligent people disagree with him or her and believe that there is a justification (even an ample justification) for belief in god. The debate about the existence of God is in a stalemate, and likely always will be. This being the case, what is wrong with inculcating theism, on the ground that it is likely to have a deterrent effect on those bent on horrific mischief?

More can be said, obviously. Suppose, for the sake of argument, that there is a proof of the nonexistence of God. The question before us is not whether theism is true, or even justified, but whether it is useful. A belief can be useful even if false or unjustified (or both), just as a belief can be useless even if true and justified. (We might call the former a useful falsehood and the latter a useless truth.) If the choice is between 1) deterring a prospective mass murderer by fooling him or her (i.e., by inducing him or her to have a false or unjustified belief) and 2) refraining from inculcating a false or unjustified belief, with the result that a ${ }^{36}$ The only people who know whether God exists are people who have died, and they're not talking. 
mass murder occurs, which would you choose? Most reasonable people, I suspect, would choose the former. So let the inculcation of theism begin, and leave the niceties of proof, disproof, and argumentation about the ethics of inculcating false beliefs to philosophers and theologians. There are innocent lives at stake.

\section{Conclusion}

It has been said that in philosophy, unlike other disciplines, everything is up for grabs - though not all at once! The debate about whether to confiscate firearms (i.e., to prohibit and punish private firearms possession) is an important debate, with empirical, moral, and legal dimensions, but it shows no signs of abating, partly, perhaps, because emotions run high on both sides. I have bracketed this particular debate in order to see what else (besides the confiscation of firearms) might be done to prevent school shootings and other mass homicides. I have suggested that punishments long since banished in civilized societies, such as ignominious death and burial, torture, and imprisonment with hard labor, be revived. The idea is not merely to increase the severity of punishments, but to take account of the fact that some or many mass murderers are not afraid to die. How, if at all, can individuals such as this-with this psychology-be deterred ${ }^{37}$

The answer is that they can be deterred by threatening them with something that they view as worse than death. What this something is will differ by person (since psychologies differ), but it stands to reason that punishments such as ignominious death, ignominious burial, torture, hard labor, and denial of Internet access (including social media) will be viewed by many prospective mass murderers as frightening (even horrifying) and, therefore, unacceptable. If even one mass murderer is deterred by threats such as these, then, by definition, two or more innocent lives will have been saved.

How many mass murders can we expect to prevent by adopting such punishments? Law professors Cass Sunstein and Adrian Vermeule (2005: p. 706) cite research to the effect that each executed death sentence saves 18 innocent lives. These lives belong to real people, even though, in the nature of things, we don't know their identities. They have hopes, dreams, joys, experiences, families, friends, and projects, just as you and I do. Many of them, such as the victims of the Santa Fe school shooter, have only recently embarked on life's journey. If deterrence of this magnitude can be achieved by imposing the punishments suggested in this essay, the world will be a much better place, morally speaking. Do we not owe it to ourselves (and to our loved ones) to make the attempt? If things turn out other than as we hope (and expect), we can always go back. $^{38}$

${ }^{37}$ That a person is undeterred (by existing punishments) does not mean that he or she is undeterrable (by any punishments). All undeterrable people are undeterred, but not all undeterred people are undeterrable. Formally, ' $x$ is undeterrable' is the superaltern of ' $x$ is undeterred', meaning that the former entails, but is not entailed by, the latter. My aim in this essay is not to deter the undeterrable, which is akin to squaring the circle, but to find ways to deter the deterrable. 


\section{Acknowledgements}

This essay is dedicated to the memory of the men, women, and children-especially the children-whose precious lives have been destroyed by mass murderers. May the suggestions made in this essay go some way toward reducing the number of such victims.

\section{Conflicts of Interest}

The author declares no conflicts of interest regarding the publication of this paper.

\section{References}

(1963). Abington School District v. Schempp, 374 U.S. 203.

Bentham, J. (1996). An Introduction to the Principles of Morals and Legislation. Oxford: Clarendon Press.

Bentham, J. (1843). Principles of Penal Law. In J. Bowring (Ed.), The Works of Jeremy Bentham (Vol. 1, pp. 365-580). Edinburgh: William Tait.

(1979). Black's Law Dictionary (5th Ed.). St. Paul, MN: West Publishing Company.

(1986). Bowers v. Hardwick, 478 U.S. 186.

Boyer, E. (1992). Teaching Religion in the Public Schools and Elsewhere. Journal of the American Academy of Religion, 60, 515-524. https://doi.org/10.1093/jaarel/LX.3.515

Burgess-Jackson, K. (1982). The Legal Status of Suicide in Early America: A Comparison with the English Experience. Wayne Law Review, 29, 57-87.

Child, J. W. (1999). Deterrent Rationale. In C. B. Gray (Ed.), The Philosophy of Law: An Encyclopedia (pp. 201-203). New York and London: Garland Publishing.

\footnotetext{
${ }^{38}$ I know from personal experience that I will be attacked, both personally and professionally, for publishing this essay. It will be said, for example, that I "advocate" or "endorse" torture, the implication being that this is sadistic, depraved, or otherwise beyond the pale. Let me preempt these attacks. First, I distinguished, in footnote 5 , between punitive, interrogational, and sadistic torture. I wrote there that "I have nothing to say about interrogational or sadistic torture (from which it follows that I neither defend nor endorse them)." How can I be accused of sadism when 1) I neither defend nor endorse sadistic torture and 2) nothing I say commits me logically to defending, endorsing, or otherwise supporting sadistic torture? My motive in writing this essay is altruistic; I am trying to save innocent lives (such as those of my attackers).

Second, I do not "advocate" or "endorse" even punitive torture. As I explained early in the essay, I am trying to explain, philosophically (recall the discussion of Nozick in footnote 4), how it is possible to deter someone who is willing (even eager) to die. I am saying to policymakers, in effect, "If you want to deter prospective mass murderers (including school shooters), then you should consider torturing duly convicted mass murderers, for that (unlike capital punishment) has at least a chance of succeeding."

Third, just as some philosophers advocate or endorse the killing of babies (via abortion or infanticide) for the convenience of the babies' mothers, some philosophers advocate or endorse torture. Peter Singer, for example, who is Ira W. DeCamp Professor of Bioethics in the University Center for Human Values at Princeton University, endorses torture of innocent children as a means of preventing equal or greater suffering by other children or adults. (See the second epigraph of this essay.) According to Singer, torture in such cases is not merely permissible; it is obligatory. By contrast, am suggesting (not advocating or endorsing) torture of duly convicted mass murderers (not innocent children) as a means of preventing the deaths (not merely suffering) of innocent persons.

It's a sad commentary on our society (and on academia in particular) that one cannot have a serious philosophical discussion of certain topics, such as torture, without being vilified, abused, and threatened with personal or professional harm. Thank God for tenure.
} 
(2008). District of Columbia v. Heller, 554 U.S. 570.

(1962). Engel v. Vitale, 370 U.S. 421.

Feinberg, J. (1984). The Moral Limits of the Criminal Law. Vol. 1, Harm to Others. New York and Oxford: Oxford University Press.

Fernandez, M., Fausset, R., \& Bidgood, J. (2018). In Texas School Shooting, 10 Dead, 10 Hurt and Many Unsurprised. New York Times, May 18, 2018.

https://www.nytimes.com/2018/05/18/us/school-shooting-santa-fe-texas.html

Geis, G. (1955). Pioneers in Criminology: VII. Jeremy Bentham (1748-1832). The Journal of Criminal Law, Criminology, and Police Science, 46, 159-171. https://doi.org/10.2307/1139837

Gomez, M. (2018). Man on Stabbing Spree Targeted Children at a 3-Year-Old's Birthday Party, Police Say. New York Times, July 1, 2018.

https://www.nytimes.com/2018/07/01/us/mass-stabbing-boise-idaho.html

Graydon, C. F. (1999). Rehabilitation and Habilitation Rationale. In C. B. Gray (Ed.), The Philosophy of Law: An Encyclopedia (pp. 730-732). New York and London: Garland Publishing.

Greenawalt, K. (2005). Does God Belong in Public Schools? Princeton, NJ, and Oxford: Princeton University Press.

Grossman, D., Paulsen, K., \& Miserany, K. (2016). Assassination Generation: Video Games, Aggression, and the Psychology of Killing. New York: Little, Brown and Company.

Healy, J., Fernandez, M., \& Blinder, A. (2018). On a Spring Texan Morning, a Sound Heard Too Often at Schools Across America: Bang. Bang. Bang. New York Times, May 19, 2018. https://www.nytimes.com/2018/05/19/us/texas-santa-fe-school-shooting.html

Juratowitch, B. (2008). Torture Is Always Wrong. Public Affairs Quarterly, 22, 81-90.

Kant, I. (1997). Lectures on Ethics. Cambridge: Cambridge University Press. https://doi.org/10.1017/CBO9781107049512

Kershnar, S. (1997-1998). An Argument for the Use of Torture as Punishment. Hamline Journal of Public Law \& Policy, 19, 497-528.

(2003). Lawrence v. Texas, 539 U.S. 558.

Mayerfeld, J. (2008). In Defense of the Absolute Prohibition of Torture. Public Affairs Quarterly, 22, 109-128.

(2010). McDonald v. Chicago, 561 U.S. 742.

(2012). Miller v. Alabama, 567 U.S. 460.

(2010). New Oxford American Dictionary(3rd ed.). New York: Oxford University Press.

Nozick, R. (1981). Philosophical Explanations. Cambridge, MA: Belknap Press of Harvard University Press.

Oliver, N. (2010). A History of Scotland. London: Phoenix.

O’Neill, O. (1991). Ch. 7: Which Are the Offers You Can’t Refuse? In R. G. Frey \& C. W. Morris (Eds.), Violence, Terrorism, and Justice (pp. 170-195). Cambridge: Cambridge University Press. https://doi.org/10.1017/CBO9780511625039.008

(2005). Roper v. Simmons, 543 U.S. 551.

Shue, H. (2005). Torture in Dreamland: Disposing of the Ticking Bomb. Case Western Reserve Journal of International Law, 37, 231-239.

Singer, P. (2016). Twenty Questions. Journal of Practical Ethics, 4, 67-78.

Stace, W. T. (1948). Man against Darkness. The Atlantic Monthly, 182, 53-58. 
Sunstein, C. R., \& Vermeule, A. (2005). Is Capital Punishment Morally Required? Acts, Omissions, and Life-Life Tradeoffs. Stanford Law Review, 58, 703-750.

https://doi.org/10.2139/ssrn.691447

(1971). The Compact Edition of the Oxford English Dictionary. Oxford: Oxford University Press.

(1999). The Oxford American Dictionary and Language Guide. New York and Oxford: Oxford University Press.

Thomson, J. J. (1971). A Defense of Abortion. Philosophy \& Public Affairs, 1, 47-66. https://doi.org/10.1007/978-1-4615-6561-1_6

Twining, W. L., \& Twining, P. E. (1973). Bentham on Torture. Northern Ireland Legal Quarterly, 24, 305-356.

Von Hirsch, A. (1999). Incapacitative Rationale. In C. B. Gray (Ed.), The Philosophy of Law: An Encyclopedia (pp. 395-396). New York and London: Garland Publishing.

Waldron, J. (2005). Torture and Positive Law: Jurisprudence for the White House. Columbia Law Review, 105, 1681-1750. 